Dhaka Univ. J. Sci. 62(2): 81-86, 2014 ((July)

\title{
Investigating Causal Relations of Economic Variables: Capital, GDP, Labour and Population in Sweden 1870-2000
}

\author{
Mohammad Mastak Al Amin ${ }^{1 *}$, Anamul Haque Sajib ${ }^{2}$ and Mohammad Alamgir ${ }^{3}$ \\ ${ }^{1}$ BRAC University, Mohakhali, Dhaka, Bangladesh \\ ${ }^{2}$ Department of Statistics, Biostatistics and Informatics, Dhaka University, Dhaka-1000 Bangladesh \\ ${ }^{3}$ Institute of Cost and Management Accountants of Bangladesh, Dhaka, Bangladesh
}

(Received: 6 October 2012; Accepted: 4 May 2014)

\begin{abstract}
The main objective of this paper was to study the causal relationships of the economic variables GDP, labour, capital and population in Sweden during the time period 1870 to 2000. In this paper the theory of unit root tests, vector auto regressive (VAR) model and GrangerCausality test were ased to find the causality of the variables. Augmented Dickey Fuller test was also used as unit root test. By applying all these tests and methods, the causal relationship among the economic variables has been established.
\end{abstract}

Key words: GDP, labour, capital, population, VAR model, Granger-Causality test

\section{Introduction}

Sweden is a country of high level of living standard and a well-developed social welfare system. Wallin and $\mathrm{Kwam}^{1}$ stated that one striking feature of Sweden is its ageing population. Low fertility rates, demographic effects of the baby booms, high life expectancy rates lead to fall in labour supply. This has serious implications for the labour market.

Economic growth is a subject that was a subject of rigorous research in the preceding decade. The empirical research about economic growth, one of the first studies was done by $\mathrm{Baumol}^{(\mathrm{R})}$, he argued the identical group of countries raised according the notion of convergence whereas the set of heterogeneous countries carried on divergence processes. Then it was carried out by Barro and Mankiww et al. ${ }^{(\mathrm{R})}$ They were mostly based on two methods: first one was economic growth regressed with GDP level \& other determinants, the second one was economic growth regressed on the initial income stage \& the variables conclude the stable state of a given country ${ }^{2}$.

Recently, a number of articles have deal with the question of the temporal interdependence between economic variables GDP, labour, capital and the demographic variable population these papers focused narrowly about what theory foretells the timing of movements of economic \& demographic variables and to what extent it is definite or rejected by empirical facts ${ }^{3}$.

To consider Sweden for this study is interesting because of the country's dissimilar evolution of the year ${ }^{4}$.

We provide in this paper the actual causal relationships about the economic factors which confer to understand the major problems and key developments of the centrally planned economy.

Here we attempt to evaluate the causality effects of the economic and demographic variables of Sweden:

i) GDP to labour, capital and population

ii) Capital to GDP, labour and population

iii) Labour to GDP, capital and population

iv) Population to GDP, labour and capital

\section{Theory and Background}

There exists a wealth of literature on the impact and the casual relationship of economic and demographic variables. Previous studies depended mainly on cross-sectional or panel data to examine the causal relationships between the economic variables. Estimation procedures deal with the bias due to include permanent effects in dynamic panels engage transformations of the model, e.g. consider taking first difference that would be a solution to reduce long run variation in the variables ${ }^{5}$.

The data set containing the variables are GDP, labour, capital and population. The production function can be written in the form:

$\mathrm{Y}_{\mathrm{t}}=\mathrm{F}(\mathrm{L}, \mathrm{K}, \mathrm{P} ; \mathrm{t})$

Where $\mathrm{Y}$ is GDP, $\mathrm{L}$ is labour, $\mathrm{K}$ is capital and $\mathrm{P}$ refers to the population.

\section{Stationarity}

A time series data is said to be stationary data if it has the following characteristics:-

-its mean and variance are constant over time.

-the covariance between two values from the time series depends only on the length of time ${ }^{6}$.

\section{Tests of Stationarity}

To check the time series data about stationarity there are many tests, one of the most acceptable test is Dickey-Fuller test ${ }^{7}$.

\section{Vector Auto-regression (VAR)}

The vector autoregressive (VAR) model is an econometric model which is used to stablishing the relationship among the econometric variables.

We compare the LR test criteria to chi-squares distribution with degrees of freedom. We also consider AIC, SC and HQIC test for finding the number of lags ${ }^{8}$.

\section{Granger Causality Test}

Granger causality test is a method for determining the causality testing among the variables those include in the model. The relationship between two variables may be uni- 
directional, bi-directional and no direction and we can find the causality in any direction or no causality by Granger causality test ${ }^{9}$.

Therefore if we conclude $\mathrm{Y}$ as a predictor to improve the prediction of $\mathrm{X}$, then $\mathrm{Y}$ is the Granger causal for $\mathrm{X}^{10}$.

The growing use of cointegration test and error correction have modified the causality tests, given that cointegration or error correction terms open an additional channel through which variables may be correlated in a Granger causal chain $^{11}$.

\section{Hypothesis}

Our null hypothesis are-
i) $\mathrm{H}_{0}$ : labour does not cause GDP
ii) $\mathrm{H}_{0}$ : GDP does not cause labour
iii) $\mathrm{H}_{0}$ : pop does not cause GDP
iv) $\mathrm{H}_{0}$ : GDP does not cause pop
v) $\mathrm{H}_{0}$ : capital does not cause labour
vi) $\mathrm{H}_{0}$ : labour does not cause capital
vii) $\mathrm{H}_{0}$ : GDP does not cause capital
viii) $\mathrm{H}_{0}$ : capital does not cause GDP
ix) $\mathrm{H}_{0}$ : pop does not cause capital
x) $\mathrm{H}_{0}$ : capital does not cause pop
xi) $\mathrm{H}_{0}$ : labour does not cause pop
xii) $\mathrm{H}_{0}$ : pop does not cause labour

\section{Data}

The data set of growth accounting data consists of the economic variables GDP, Labour, Capital and Population spanning the period of 1870 to 2000. The dataset collect from the website of Economic History department, Lund University, Sweden. The database in the Economic History departmental website is always accessible for the students of the department. The source of the data is provided in the departmental website of Lund University.

\section{Methodology}

We want to analyze the dataset to find out the causal relationship between the variables GDP, labour, capital and population. First we check our data set for missing values. If there is any missing values we drop them, otherwise it influences the causal relationship. Before testing the causality we need to switch the data set to natural logarithms and then examine the stationarity of all the variables that we consider, as we know the logarithmic time series provides the values in terms of percentages. We can have an idea from the ocular inspection by doing two way lines of the variables with time which provides decision about the stationarity.

We investigated the stationarity of the series by unit root test of Augmented Dickey Fuller test. The test conclude the lag values, constant and trend. Usually the data set may be stationary after taking first or second differences.

After obtaining stationary data we go for the Granger causality test. Initially we check the cointegration of the data set and then go for best lag length for the VAR time series by VAR lag order selection criteria. Then we test the data set by Granger causality test by pair wise.

\section{Analysis of the Data and Results}

Test for stationarity by ocular inspection, the line diagrams for the variables are given below-

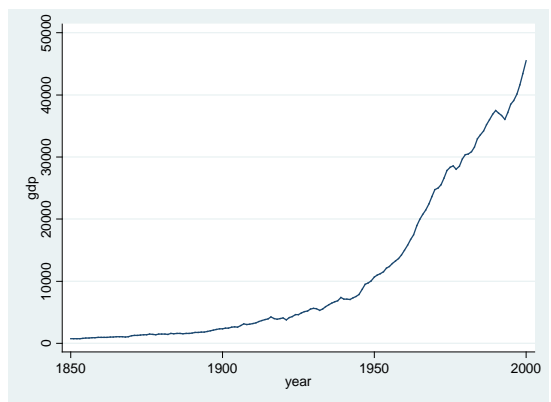

Fig. 1. Ocular inspection for stationarity of GDP

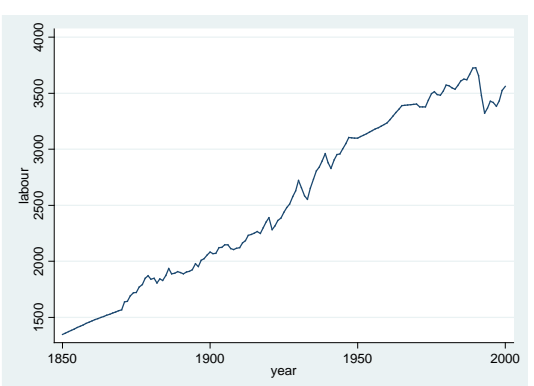

Fig. 2. Ocular inspection for stationarity of Labor

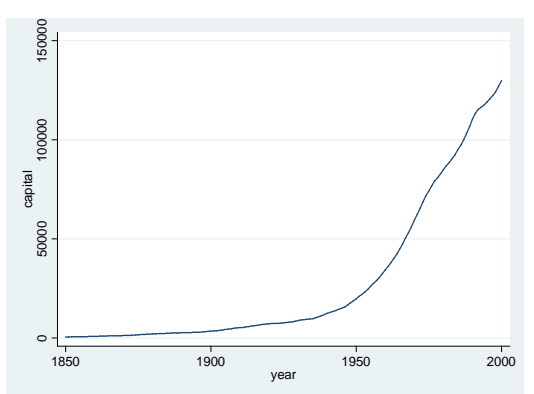

Fig. 3. Ocular inspection for stationarity of capital

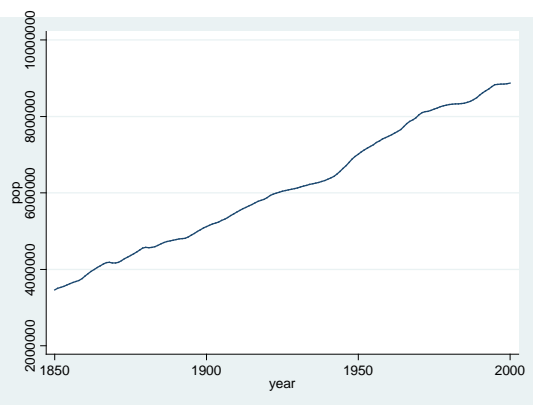

Fig. 4. Ocular inspection for stationarity of population

We find from the Fig.1, Fig.2, Fig.3 and Fig.4 for the variables, all the line graphs depict that the series are non 
stationary and must have a trend over time. For calculating lag we may check the autocorrelation of these variables from the following figures-

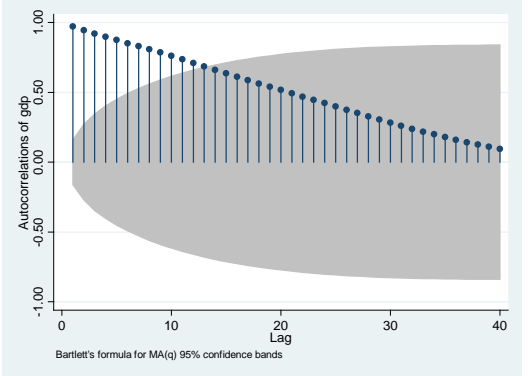

Fig. 5. Ocular inspection of lag selection for GDP

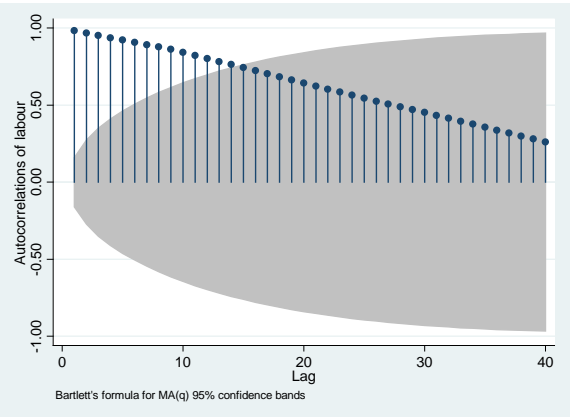

Fig. 6. Ocular inspection of lag selection for Labour

We have seen that there are more than ten lags for each variable included in the model, but for convenience we consider only five lags which gave us better outcomes. Now we perform the Augmented Dickey Fuller Test for making decision about the stationarity.

Table 1. Augmented Dickey Fuller Test results for stationarity

\begin{tabular}{|l|l|l|l|}
\hline GDP & $\begin{array}{l}\text { Augmented } \\
\text { Dickey Fuller } \\
\text { Test Statistic }\end{array}$ & t- statistics & 1.232 \\
\hline Labour & $\begin{array}{l}\text { Augmented } \\
\text { Dickey Fuller } \\
\text { Test Statistic }\end{array}$ & t- statistics & -1.537 \\
\hline Capital & $\begin{array}{l}\text { Augmented } \\
\text { Dickey Fuller } \\
\text { Test Statistic }\end{array}$ & t- statistics & 0.703 \\
\hline Population & $\begin{array}{l}\text { Augmented } \\
\text { Dickey Fuller } \\
\text { Test Statistic }\end{array}$ & t- statistics & -2.057 \\
\hline \multirow{2}{*}{ Critical Values } & $1 \%$ level & -4.025 \\
\cline { 3 - 4 } & & $5 \%$ level & -3.444 \\
\cline { 3 - 5 } & & $10 \%$ level & -3.144 \\
\hline
\end{tabular}

The above table provides the summary of Augmented Dickey Fuller test. According to the test statistic values of all the variables GDP, labour, capital and population are $1.232,-1.537,0.703$ and -2.057 respectively which are greater than the critical value of -3.444 at $5 \%$ level of significance as well as $1 \%$ level of significance. So we may not reject our null hypothesis that all the four variables of the time series have a unit root. So we conclude that the series are non stationary.
From the above result we see that the series are nonstationary for all the four variables GDP, labour, capital and population. But to test the causality we need to get them as stationary. Therefore we take their first differences as: d_ln_GDP,d_ln_labour, d_ln_capital and d_ln_pop, then check about the stationarity by the previous procedure.

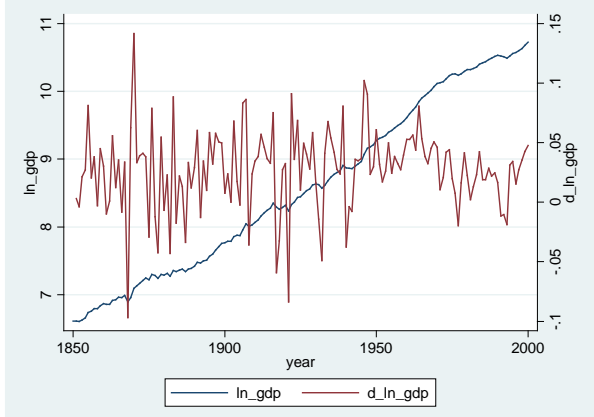

Fig. 7. Ocular inspection for stationarity of $1^{\text {st }}$ difference of GDP

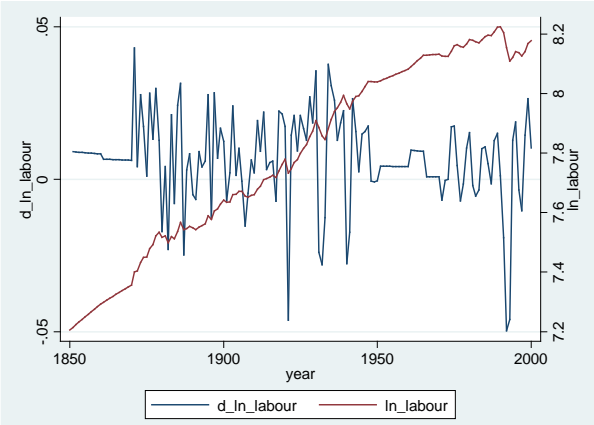

Fig. 8. Ocular inspection for stationarity of $1^{\text {st }}$ difference of Labour

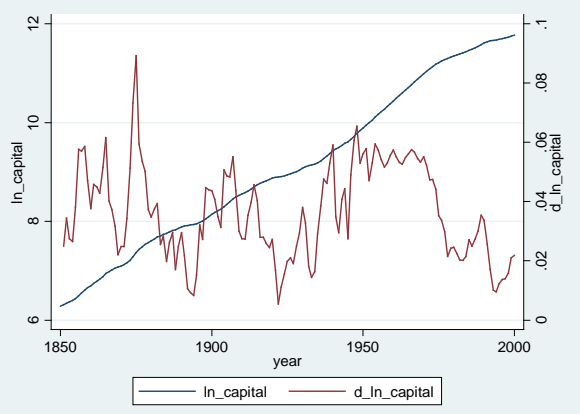

Fig. 9. Ocular inspection for stationarity of $1^{\text {st }}$ difference of Capital

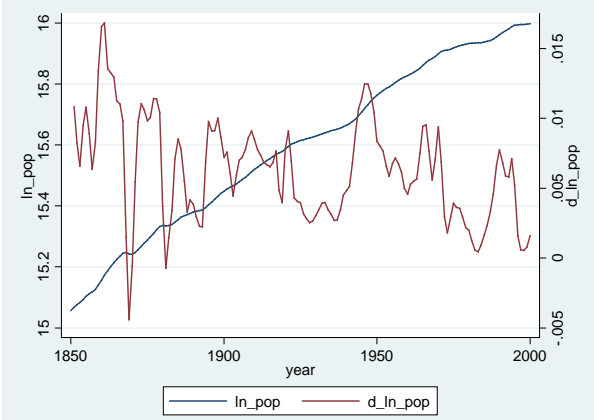

Fig. 10. Ocular inspection for stationarity of $1^{\text {st }}$ difference of population

It is clear from the Fig.7, Fig.8, Fig.9 and Fig.10 for the first differences and the logarithmic series of the variables the line graphs show that the logarithmic series of the variables are non stationary and must have a trend over time whereas 
the first differences of the four variables now look stationary.

Again by Augmented Dickey Fuller test we get the decision about lags from the figure auto correlation of the variables.

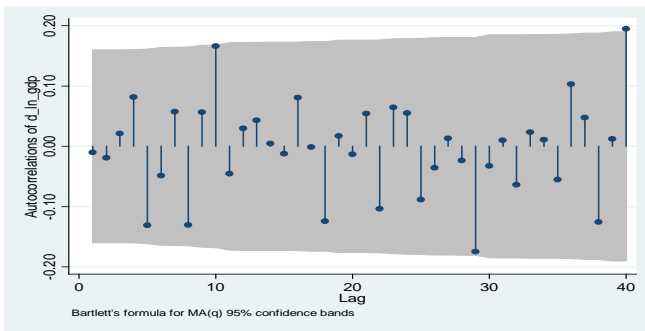

Fig. 11. Ocular inspection of lag selection for $1^{\text {st }}$ difference of GDP

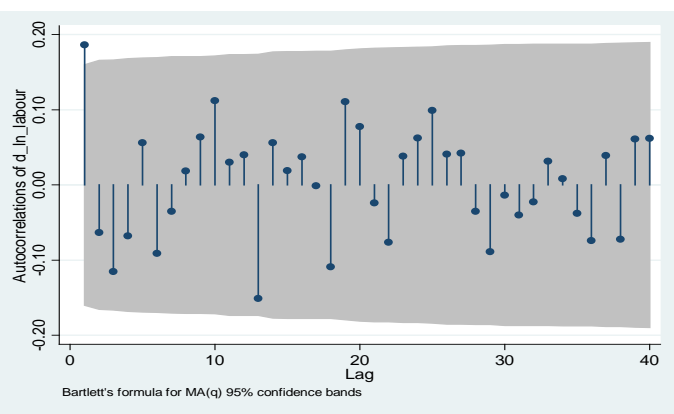

Fig. 12. Ocular inspection of lag selection for $1^{\text {st }}$ difference of Labour

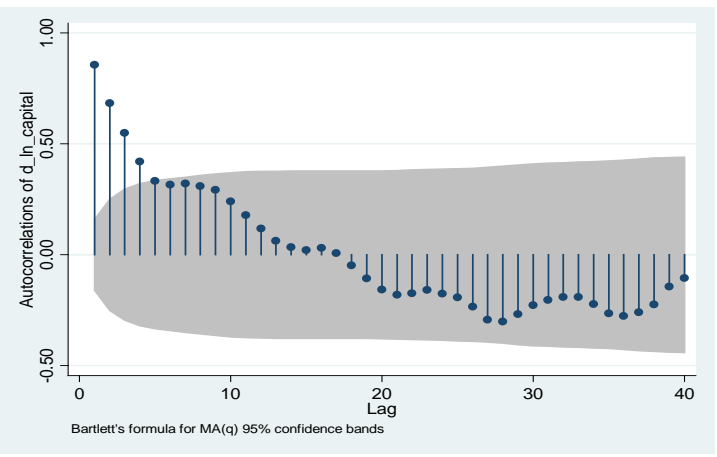

Fig. 13. Ocular inspection of lag selection for $1^{\text {st }}$ difference of capital

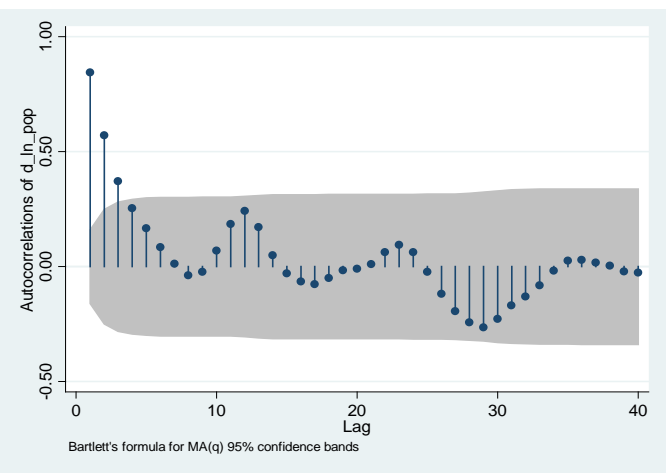

Fig. 14. Ocular inspection of lag selection for $1^{\text {st }}$ difference of population

We get from the above four figures (Fig.11 to Fig.14) that the first difference of GDP doesn't need to add any lags but the first difference of the variables labour, capital and population need to add 1 lag, 4 lags and 3lags respectively. Again we apply Augmented Dickey Fuller Test for making decisions about the stationarity and the output of the test which is given below-

Table 2. Augmented Dickey Fuller Test results for stationarity of 1st differences

\begin{tabular}{|c|c|c|c|}
\hline d_ln_GDP & $\begin{array}{l}\text { Augmented } \\
\text { Dickey Fuller } \\
\text { Test Statistic }\end{array}$ & t- statistics & -12.255 \\
\hline d_ln_labour & $\begin{array}{l}\text { Augmented } \\
\text { Dickey Fuller } \\
\text { Test Statistic } \\
\end{array}$ & t- statistics & -8.483 \\
\hline d_ln_capital & $\begin{array}{l}\text { Augmented } \\
\text { Dickey Fuller } \\
\text { Test Statistic }\end{array}$ & t- statistics & -5.333 \\
\hline d_ln_population & $\begin{array}{l}\text { Augmented } \\
\text { Dickey Fuller } \\
\text { Test Statistic }\end{array}$ & t- statistics & -4.255 \\
\hline \multirow{3}{*}{\multicolumn{2}{|c|}{ Critical Values }} & $1 \%$ level & -4.025 \\
\hline & & $5 \%$ level & -3.444 \\
\hline & & $10 \%$ level & -3.144 \\
\hline
\end{tabular}

The table provides the summary results of the test. We get the test statistic values for the first differences of all the variables GDP, labour, capital and population are -12.255, $8.483,-5.333$ and -4.255 respectively which are less than the critical value -3.444 at $5 \%$ level of significance as well as $1 \%$ level of significance. Therefore, we may reject the null hypotheses that the first difference of all the four varibles of the time series does not have a unit root.So we conclude that the series are stationary.

Now we check the co-integration of residual's ocular inspection and then check it by test:-

Here our null hypothesis is-

$\mathrm{H}_{0}$ : the series is not co-integrated.

We check it by ADF test, because if it is stationary then we can say that the series is co-integrated.

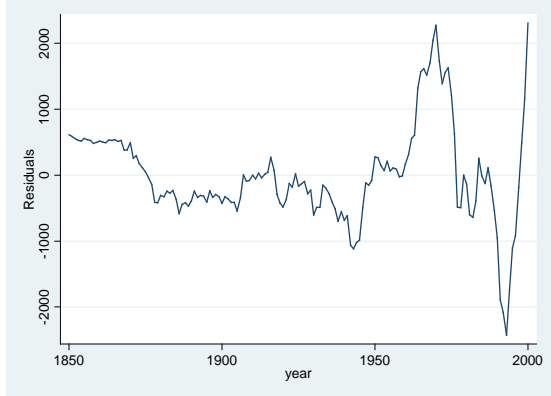

Fig. 15. Ocular inspection for stationarity of residual 


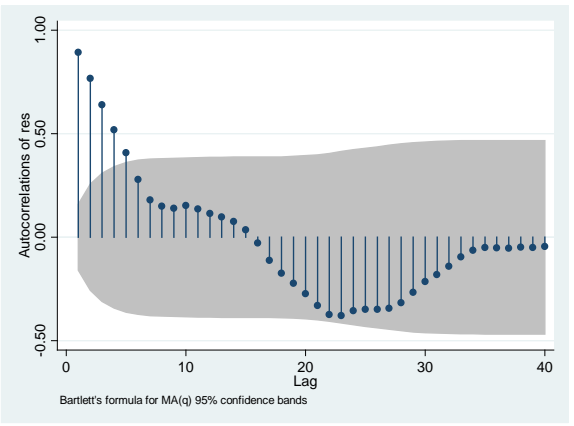

Fig. 16. Lag selection of residual for ADF test

It is clear from the figures (Fig.15 \& Fig.16) of residual series with time; the line graphs show that the residual of the variables are stationary. From the auto correlation graph of the residual we get 5 lags. Again we test for the stationarity by Augmented Dickey Fuller test similar to previous way.

Table 3. Augmented Dickey Fuller test results for unit root

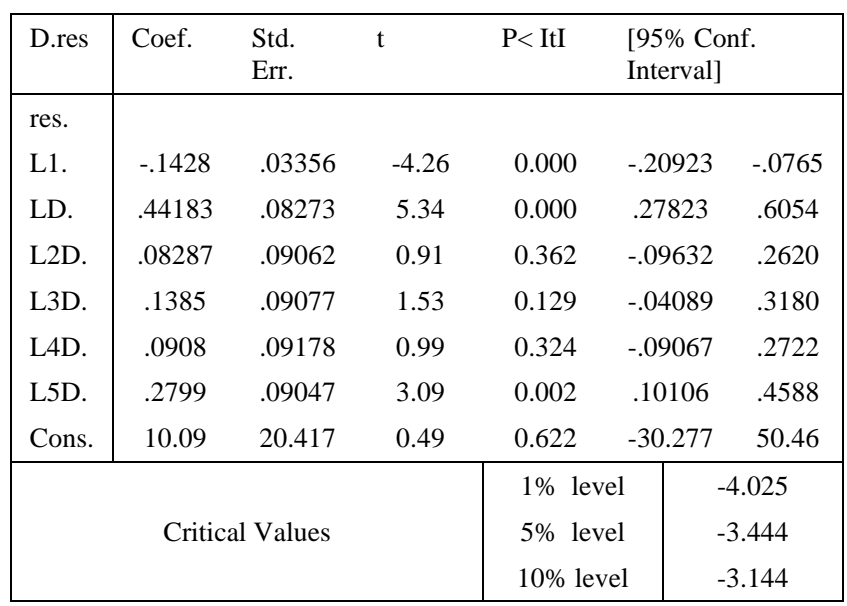

We get our test statistic value (-4.257) is less than the critical value $(-3.444)$ at $5 \%$ level of significance. So we may reject our null hypothesis that our series may be stationary and the series is co-integrated. So we get the series stationary and co-integrated of the residuals are of order zero.

To find the lag order we use VAR lag order selection criteria.

Table 4. VAR lag order selection criteria results

\begin{tabular}{|c|c|c|c|c|c|c|c|c|}
\hline $\begin{array}{l}\mathbf{a} \\
\mathrm{g}\end{array}$ & $\mathbf{L L}$ & LR & df & $\mathbf{p}$ & FPE & AIC & HQIC & SBIC \\
\hline 0 & 1737.35 & & & & $5.7 \mathrm{e}-16$ & -23.745 & -23.712 & -23.663 \\
\hline 1 & 1963.52 & 452.3 & 16 & .000 & 3.2e-17 & -26.624 & -26.458 & $\begin{array}{c}- \\
26.215^{*}\end{array}$ \\
\hline 2 & 2002.02 & 77.01 & 16 & .000 & $2.4 e-17$ & -26.932 & $26.633^{*}$ & -26.196 \\
\hline 3 & 2021.57 & 39.11 & 16 & .001 & $\begin{array}{c}2.3 e- \\
17^{*} \\
\end{array}$ & $\begin{array}{c}- \\
26.981^{*} \\
\end{array}$ & -26.549 & -25.918 \\
\hline 4 & 2037.18 & 31.21 & 16 & .013 & $2.3 e-17$ & -26.975 & -26.411 & -25.586 \\
\hline
\end{tabular}

According to the results of VAR lag order selection criteria we make the decision to take 3 lags, this is because from the table we have seen that FPE and AIC choose 3 lags whereas SBIC choose 1 lag, HQIC prefer 2 lags and LR select 4 lags. Here we consider the goodness of fit for the model so that we should take the number of lags which is chosen by the majority of the information criteria. And finally we find 3 lags are optimal for the time series data.

After that we do formal test about the co-integration by Johansen test because here we have more than two variables whether we always used Engle-Granger test for cointegration.

Our null hypothesis for testing co-integration by Johansen test is given below:

Ho: There is no co-integration

$\mathrm{H} 1$ : There is at least 1 co-integration relationship present.

If our null hypothesis is rejected we go for next step.

Table 5. Johansen test results for cointegration

\begin{tabular}{|c|c|c|c|c|c|}
\hline $\begin{array}{c}\text { maxim } \\
\text { um } \\
\text { rank }\end{array}$ & $\begin{array}{c}\text { par } \\
\text { ms }\end{array}$ & LL & $\begin{array}{c}\text { eigen } \\
\text { value }\end{array}$ & $\begin{array}{c}\text { trace } \\
\text { statistics }\end{array}$ & $\begin{array}{c}5 \% \\
\text { Critical } \\
\text { value }\end{array}$ \\
\hline 0 & 36 & 2028.2938 & & 55.7221 & 47.21 \\
\hline 1 & 43 & 2042.4641 & 0.17427 & $27.3813^{*}$ & 29.68 \\
\hline 2 & 48 & 2051.478 & 0.11468 & 9.3536 & 15.41 \\
\hline 3 & 51 & 2055.5891 & 0.05404 & 1.1314 & 3.76 \\
\hline 4 & 52 & 2056.1548 & 0.00762 & & \\
\hline
\end{tabular}

Here we consider the logarithmic series to find out the cointegration relationships and see whether the series we get stationary after taking their first differences, because we want to know is the co-integration of the original series. We consider 3 lags from the lag selection criteria which we use here.

From the test we have seen that the trace statistic value with rank 1 is 27.3813 which is less than the critical value 29.68. It provides us not to reject our null hypothesis. So we can say that there is at most one co-integration in our series.

Later us do the Granger causality test for determining the causes.

Table 6. Granger Causality test results

\begin{tabular}{|c|c|c|c|c|}
\hline Equation & Excluded & chi2 & df & Prob $>$ chi2 \\
\hline d_ln_gdp & d_ln_labour & 4.3437 & 3 & 0.222 \\
\hline d_ln_gdp & d_ln_capital & 4.5691 & 3 & 0.206 \\
\hline d_ln_gdp & d_ln_pop & 1.4357 & 3 & 0.697 \\
\hline d_ln_gdp & ALL & 8.7738 & 9 & 0.458 \\
\hline d_ln_labour & d_ln_gdp & 0.45881 & 3 & 0.928 \\
\hline d_ln_labour & d_ln_capital & 1.954 & 3 & 0.582 \\
\hline d_ln_labour & d_ln_pop & 1.9223 & 3 & 0.589 \\
\hline d_ln_labour & ALL & 4.3709 & 9 & 0.885 \\
\hline d_ln_capital & d_ln_gdp & 24.192 & 3 & 0.000 \\
\hline d_ln_capital & d_ln_labour & 25.083 & 3 & 0.000 \\
\hline d_ln_capital & d_ln_pop & 7.7618 & 3 & 0.051 \\
\hline d_ln_capital & ALL & 93.384 & 9 & 0.000 \\
\hline d_ln_pop & d_ln_gdp & 3.5978 & 3 & 0.308 \\
\hline d_ln_pop & d_ln_labour & 1.3563 & 3 & 0.716 \\
\hline d_ln_pop & d_ln_capital & 8.1328 & 3 & 0.043 \\
\hline d_ln_pop & ALL & 16.934 & 9 & 0.050 \\
\hline
\end{tabular}

We test the pair-wise comparison of the variables GDP, labour, capital and population of the time series data. 
Table 7. Summary test results of pair wise comparison of the variables

\begin{tabular}{|c|c|c|}
\hline Null hypothesis $\left(\mathbf{H}_{0}\right)$ & $P$ value & Decision \\
\hline labour does not cause GDP & 0.2777 & We may not reject $\mathrm{H}_{0}$ \\
\hline GDP does not cause labour & 0.928 & We may not reject $\mathrm{H}_{0}$ \\
\hline pop does not cause GDP & 0.697 & We may not reject $\mathrm{H}_{0}$ \\
\hline GDP does not cause pop & 0.308 & We may not reject $\mathrm{H}_{0}$ \\
\hline capital does not cause labour & 0.582 & We may not reject $\mathrm{H}_{0}$ \\
\hline labour does not cause capital & 0.000 & We may reject $\mathbf{H}_{0}$ \\
\hline GDP does not cause capital & 0.000 & We may reject $\mathrm{H}_{0}$ \\
\hline capital does not cause GDP & 0.206 & We may not reject $\mathrm{H}_{0}$ \\
\hline pop does not cause capital & 0.051 & We may not reject $\mathrm{H}_{0}$ \\
\hline capital does not cause pop & 0.043 & We may reject $\mathbf{H}_{0}$ \\
\hline labour does not cause pop & 0.716 & We may not reject $\mathrm{H}_{0}$ \\
\hline pop does not cause labour & 0.589 & We may not reject $\mathrm{H}_{0}$ \\
\hline
\end{tabular}

Pair-wise comparison

\section{i) GDP \& labour}

According to the tabulated value, the p-values are $0.2777 \&$ 0.928 for the null hypotheses about the causes of GDP \& labour and the values are significant for both the cases at $5 \%$ level of significance. So we may not reject the null hypothesis and conclude that labour doesn't have Granger cause of GDP and also GDP doesn't Granger cause of labour.

\section{ii) Population \& GDP}

Here the p-values are $0.697 \& 0.308$ respectively for pop \& GDP and these are significant at $5 \%$ level of significance; we may not reject the null hypothesis. So pop doesn't have Granger cause of GDP and vice versa.

iii) Capital \& labour

According to the table the p values are $0.582 \&$ 0.000.So we may not reject our null hypothesis that capital doesn't cause labour but we may reject the null hypothesis that labour doesn't cause capital at 5\% level of significance. Therefore labour has an effect on capital.

\section{iv) GDP \& capital}

The p values for the two null hypotheses of GDP \& capital are $0.000 \& 0.206$ respectively which provide that we may reject our null hypothesis that GDP doesn't cause capital and we may not reject the null hypothesis that capital doesn't cause GDP at 5\% level of significance. So GDP has an effect on capital

\section{v) Population \& capital}

From the table the p values are $0.051 \& 0.043$. So we may not reject that the pop doesn't have Granger cause of capital whereas we may reject that capital doesn't have Granger cause that capital affect the population.

\section{vi) Labour \& pop}

For the null hypothesis of Granger cause of labour \& pop we may not reject our null hypothesis as we have the pvalues 0.716 and 0.589 which are greater than the critical value at $5 \%$ level of significance. So labour doesn't have
Granger cause of pop and pop also doesn't have Granger cause of labour.

\section{Conclusion}

For the causal effects of the economic variables of Sweden, we tested the data set and get the non stationary result of our dataset. We get our data set stationary after taking the first difference at the level of significance $1 \%$ and $5 \%$ with different lag lengths. 
By VAR lag order selection criteria we get 3 lags for cointegration and Granger Causality test. We consider the logarithmic series to find out the co-integration. From the test result we find the trace statistic value is 27.3813 less than the critical value 29.68 for rank 1 . Therefore it is clear that we reject the null hypothesis which is about no cointegration. Now we conclude that there is one cointegration in our series. After that we perform pair-wise Granger Causality test to find the causal relationships among the economic growth variables. According to the result of Granger-Causality test we do not get any bidirectional causality between the economic variables GDP, labour, capital and population; that mean none of the variables affect each other in the both direction. We observe that there are unidirectional causality between labour \& capital, GDP \& capital, capital \& population according to our dataset. It is clear from our causality test that labour and GDP have effect on capital and capital has an effect on population. After that we find non-directional causality between rests pairs among our variables that no one has affect to others.

\section{References}

1. Wallin, G. and B. Kwam, 2000. A Nordic Strategy for Maintaining Supply of Labor. Nordic Labour Journal. 5, 216-225.

2. Vojinivic, B., 2008. What is the causality between economic growth and its major determinants in the case of transition economics. Paper presented at the 10th bi-annual EACES conference, Moscow, 3-4.

3. Andersson, B., 1999. On the Causality Between Saving and Growth: Long and Short Run Dynamics and Country Heterogeneity. Working Paper, Department of Economics, Uppsala University, 1-2.

4. Attanasio, O., 1997. Consumption and saving behavior: modeling recent trends. Fiscal Studies. 18, 23-47.

5. Lee, K., M. H. Pesaran and R. Smith, 1997. Growth and convergence in a multi-country empirical stochastic Solow model. Journal of Applied Econometrics. 12, 357-392.

6. Adkins, L. C. and R. C. Hill, 2008. Using Stata for Principles of Econometrics. $3^{\text {rd }}$ edition, John Wiley \& Sons, 514-516.

7. Hill, R. C., E. W. Griffiths and C. G. Lim, 2008. Principles of Econometrics. John Miley \& Sons, Inc., USA, 695-697

8. Usman, S. \& F. A. A. Sarpong, 2009. Testing Granger causality with application to Exchange rates for Swedish kronor with GB pound and US dollar. Master thesis, Department of Economic History, Lund University, Sweden, 10-11.

9. Granger, C. W. J., 1969. Investigating causal relations by econometric models and cross spectral methods. Econometrica. 37, 424-438.

10. Ramanathan, R., 2002. Introductory Econometrics with Applications. $5^{\text {th }}$ edition, Harcourt College Publishers, 322-323.

11. Granger, C. W. J., 1988. Some recent developments in a concept of causality. Journal of Econometrics. 39, 199-211. 